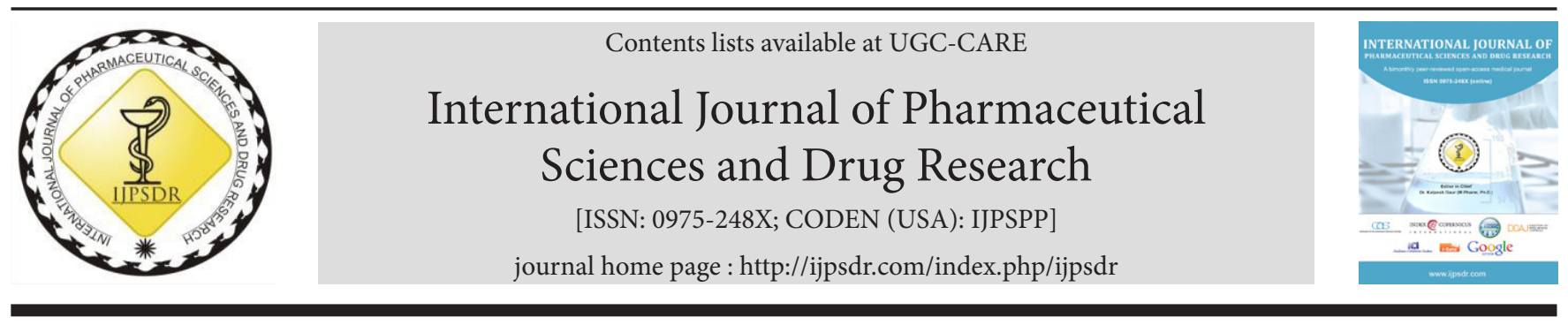

Research Article

\title{
Quality by Design (QbD) Approach for Enhancement-the Dissolution Rate of Lafutidine Liquisolid Tablets
}

\author{
Tushar Gohil $^{1 *}$, Nishant Oza ${ }^{2}$, Hitesh Vekariya ${ }^{3}$ \\ ${ }^{1}$ Department of Pharmaceutics, Smt. C. V. Gajera Pharmacy Mahila College, Amreli-65601, Gujarat, India \\ ${ }^{2}$ C. U. Shah College of Pharmacy and Research, Wadhwan City 363030, Gujarat, India \\ ${ }^{3}$ R. K. University, Rajkot-360001, Gujarat, India
}

\begin{tabular}{|c|c|}
\hline A R T I C L E I N F O & A B S T RACT \\
\hline $\begin{array}{l}\text { Article history: } \\
\text { Received: } 12 \text { February, } 2020 \\
\text { Revised: } 17 \text { April, } 2020 \\
\text { Accepted: } 30 \text { April, } 2020 \\
\text { Published: } 30 \text { May, } 2020 \\
\text { Keywords: } \\
\text { BCS class II, } \\
\text { Lafutidine, } \\
\text { Liquisolid tablet, } \\
\text { PEG-600, } \\
\text { Solubility enhancement. } \\
\text { DoI: } \\
\text { 10.25004/IJPSDR.2020.120305 }\end{array}$ & $\begin{array}{l}\text { The aim of present work was to enhancing the solubility and dissolution rate of the aquaphobic drug } \\
\text { lafutidine by liquisolid technique. Lafutidine is an } \mathrm{H}_{2} \text {-receptor antagonist BCS class II drug. Lafutidine } \\
\text { compatibility with excipients was evaluated by fourier transform infrared spectroscopy (FTIR) and } \\
\text { differential scanning calorimetry (DSC) spectrum. Preliminary trial taken to check the effect of carrier to } \\
\text { coating material ratio (R) and non-volatile solvent (PEG- } 600) \text { on pre-and post-compression characteristic. } \\
\text { Flowable liquid retention potential ( } \varnothing \text {-value) and liquid load factors }\left(\mathrm{L}_{\mathrm{f}}\right) \text { were calculated for required amount } \\
\text { of excipients necessary to preparing lafutidine liquisolid tablet. A } 3^{2} \text { full factorial design was employed } \\
\text { to check the effect of carrier to coating material ratio } \mathrm{R}\left(\mathrm{X}_{1}\right) \text { and PEG- } 600\left(\mathrm{X}_{2}\right) \text { on hardness }\left(\mathrm{Y}_{1}\right) \text {, angle } \\
\text { of repose }\left(\mathrm{Y}_{2}\right) \text {, \% of cumulative drug release at } 5 \text { minutes } \mathrm{Q} 5\left(\mathrm{Y}_{3}\right) \text {, and disintegration time }\left(\mathrm{Y}_{4}\right) \text {. Multiple } \\
\text { linear regression analysis, ANOVA, and graphical representation of the influence of factor by } 3 \mathrm{D} \text { plots were } \\
\text { performing by using Design Expert } 7.0 \text {. In this study, the following constraints were arbitrarily used for the } \\
\text { selection of an optimized batch: hardness: } 3 \text { to } 5.5 \text {, angle of repose: } 25 \text { to } 30 \text {, } \% \text { of cumulative drug release at } \\
5 \text { minutes }\left(\mathrm{Q}_{5}\right)>27.09 \% \text {, and disintegration time }<1.3 \text { minutes. The desirability value of various dependent } \\
\text { variables calculated for determining the optimized batch of tablet and it was also found to be nearer to } \\
\text { one. Performance of optimized batch had no shown any significant change at the end of stability study. }\end{array}$ \\
\hline
\end{tabular}

\section{IN TRODUCTION}

The BCS class II drugs have poor solubility and less dissolution rate in the fluid present at the absorption site. Therefore, BCS class II drugs were shown very poor bioavailability. Their bioavailability can improve by increasing the solubility and enhancement of the dissolution rate. In the last few years, so many novel techniques such as micronization, solid dispersion, inclusion complex, lyophilization, microencapsulation, and liquisolid tablets were developed to enhance the dissolution rate of aquaphobic drug. However, among them the "liquisolid tablets" is one of the most promising techniques to improve the solubility and dissolution rate. ${ }^{[1-3]}$ In liquisolid technology, the aquaphobic molecules are solubilized in a water-miscible non-volatile solvent and liquid transformed into a free-flowing, readily compressible dry powder by simple physical blending with the carrier and coating material. Liquisolid technique also improved the drug wetting property of aquaphobic drugs. Therefore, the drug dissolution profile is also improved. In addition, this technique has uncomplicated and low-cost production. ${ }^{[4]}$ Lafutidine belongs to BCS class II drug. It is an anti ulcerative agent indicated for the treatment of ulcers, and it suppresses gastric acid secretion. Lafutidine is practically poorly soluble in water. Thus, it has less than $15 \%$ bioavailability. ${ }^{[5,6]}$ Hence, the aim of the present study is made to formulate the lafutidine $10 \mathrm{mg}$ liquisolid tablets by using $3^{2}$ full factorial designs, which will improve the solubility and dissolution rate of lafutidine. In this study, the following constraints were arbitrarily used for the selection of an optimized batch: hardness: 3 to 5.5 , angle of

\footnotetext{
${ }^{*}$ Corresponding Author: Dr. Tushar A. Gohil

Address: Department of Pharmaceutics, Smt. C. V. Gajera Pharmacy Mahila College, Amreli-65601, Gujarat, India

Email $\bowtie$ : gohil1313@gmail.com

Relevant conflicts of interest/financial disclosures: The authors declare that the research was conducted in the absence of any commercial or financial relationships that could be construed as a potential conflict of interest.

Copyright (c) 2020 Tushar Gohil et al. This is an open access article distributed under the terms of the Creative Commons Attribution- NonCommercialShareAlike 4.0 International License which allows others to remix, tweak, and build upon the work non-commercially, as long as the author is credited and the new creations are licensed under the identical terms.
} 
repose: 25 to $30, \%$ of cumulative drug release at 5 minutes $\left(\mathrm{Q}_{5}\right)>27.09 \%$, and disintegration time $<1.3$ minutes.

\section{MATERIALS AND METHODS}

\section{Materials}

Lafutidine was gifted by Emcure Pharma Ltd., Mumbai. Propylene glycol, tween-80, span-80, glycerin, peg-200, peg-400, peg-600, sodium starch glycolate (SSG), polyvinyl pyrolidone K-30 (PVP K-30), andmagnesium stearate were obtained from Loba Chemicals Pvt. Ltd., Mumbai, India. Avicel PH-101, avicel PH-102, aerosil, and cab-o-sil were obtained from Chemdyes Corporation, Rajkot, India. All other materials and chemicals used were of either pharmaceutical or analytical grade.

\section{Characterization and Drug-Excipients Compatibility Study}

The maximum wavelength $\left(\lambda_{\max }\right)$ determination of the drug was done using UV spectrophotometer (Jasco V-550, Japan). Drug excipient interaction plays a vital role in achieving stability of drug in dosage form. FTIR was used to study the physical and chemical interactions between drugs and excipients. FTIR spectra of lafutidine and formulation were obtained by using the FTIR instrument (JASC0-460 Plus, Japan). DSC thermograms of lafutidine and formulations were obtained by using an automatic thermal analyzer system (Mettler Toledo DSC 821e, Mumbai, India). The analysis was performed at a rate of $20^{\circ} \mathrm{C} / \mathrm{min}$ from 50 to $300^{\circ} \mathrm{C}$ under a nitrogen flow of $20 \mathrm{~mL} / \mathrm{min}^{[7,8]}$

\section{Preliminary Screening of Non-Volatile Solvents, Carrier Materials, and Coating Materials}

\section{Selection of Non-Volatile Solvent}

Non-volatile solvent was selected based on the solubility study. The solubility of lafutidine in various non-volatile solvents, such as, propylene glycol, PEG 200, PEG 400, PEG 600 , span 80 , tween 80 , and glycerine was determined by saturated solubility method. In this method excess amount of lafutidine was added in a $2 \mathrm{~mL}$ of each vehicle, and this solution was shaken on isothermal mechanical shaker at $37 \pm 0.5^{\circ} \mathrm{C}$ for 48 hours. Supernatants were filter, weigh, and diluted with $0.1 \mathrm{~N} \mathrm{HCl}$. The drug content was analyzed by spectrophotometrically at $286 \mathrm{~nm}^{\text {[9] }}$

\section{Selection of Carrier and Coating Material}

Carrier and coating material were selected based on flowable liquid retention potential ( $\Phi$ value) and liquid load factors $\left(\mathrm{L}_{\mathrm{f}}\right)$. In preliminary, screening avicel PH 101, avicel PH 102, and lactose were taken as carrier material. In preliminary trail aerosil, aerosil 200, and cab-o-sil were taken as a coating material. The liquid retention potential ( $\Phi$ value) of a powder is the maximum amount of given non-volatile liquid that can be retained inside powder bulk (w/w) while maintaining acceptable flowability. In this study, 4 grams of coating or carrier material was mixed with increasing amount of non-volatile solvent using a mortar and pestle. Then each mixture was placed on a metal plate and at each addition angle of repose was determined. The flowable liquid-retention potential ( $\Phi$ value) of each mixture was calculated using the following equation.

$\Phi$-value $=$ Weight of liquid $/$ Weight of solid

Each mixture has specific $\Phi$ value, which were determined and plotted against respective measured angle of slide for all non-volatile liquid vehicles. The $\Phi$ value that corresponds to an angle of slide of $33^{\circ}$, was reported to represent the flowable liquid retention potentials of powder mixtures. Whereas, liquid load factors $\left(\mathrm{L}_{\mathrm{f}}\right)$ is the mass ratio $(\mathrm{w} / \mathrm{w})$ of the liquid medication to the carrier powder in the liquisolid formulation. ${ }^{[10]}$

\section{Preliminary Trial Batches of Lafutidine $10 \mathrm{mg}$ Liquisolid Tablets}

Preliminary trial of lafutidine $10 \mathrm{mg}$ liquisolid tablets was taken to check the effect of carrier to coating material ratio (R) and non-volatile solvent (PEG-600) on pre- and post-compression characteristic. Preliminary trial batches formulation of lafutidine liquisolid tablets is shown in Table 1. Trial batch of Liquisolid tablets were prepared by using PEG600 as a non-volatile solvent, avicel PH 101 as carrier material, and aerosil-200 as coating material. In this formulation, $\mathrm{Q}=\mathrm{W} / \mathrm{L}_{\mathrm{f}}$ and $\mathrm{q}=\mathrm{Q} / \mathrm{R}$. Batch $\mathrm{T} 1$ to $\mathrm{T} 5$ was canting 5 to 25 carrier to coating material ratio (R) and non-volatile solvent (PEG-600). ${ }^{[11]}$

Table 1: Formulation of preliminary trial batches

\begin{tabular}{|c|c|c|c|c|c|c|c|c|}
\hline Batch & $\begin{array}{l}\text { Lafutidine } \\
(\mathrm{mg})\end{array}$ & $\begin{array}{l}P E G-600 \\
(\mathrm{mg})\end{array}$ & $\begin{array}{l}\text { Total wt. of } \\
\text { liquid } \\
(W)(m g)\end{array}$ & $\begin{array}{l}\text { Ratio of carrier } \\
\text { to coating } \\
\text { (R) }\end{array}$ & $\begin{array}{l}\text { Liquid load } \\
\text { factor } \\
\left(L_{f}\right)\end{array}$ & $\begin{array}{l}\text { Avicel } \\
\text { PH } 101 \\
(\mathrm{mg})(\mathrm{Q})\end{array}$ & $\begin{array}{l}\text { Aerosil-200 } \\
(\mathrm{mg}) \\
(\mathrm{q})\end{array}$ & $\begin{array}{l}\text { Wt. of } \\
\text { tablets } \\
(\mathrm{mg})\end{array}$ \\
\hline $\mathrm{T} 1$ & 10 & 11.69 & 21.69 & 5 & 0.3227 & 67.21 & 13.44 & 113.6 \\
\hline $\mathrm{T} 2$ & 10 & 23.37 & 33.37 & 10 & 0.2552 & 130.76 & 13.07 & 196.71 \\
\hline T3 & 10 & 35.06 & 45.06 & 15 & 0.2326 & 193.72 & 12.9 & 279.37 \\
\hline $\mathrm{T} 4$ & 10 & 46.74 & 56.74 & 20 & 0.2214 & 256.28 & 12.81 & 361.67 \\
\hline T5 & 10 & 58.43 & 68.43 & 25 & 0.2146 & 318.87 & 12.75 & 444.05 \\
\hline
\end{tabular}




\section{$3^{2}$ Full Factorial Design for Development of Lafutidine $10 \mathrm{mg}$ Liquisolid Tablets}

Full factorial batches formulation are of lafutidine liquisolid tablets are shown in Table 2. In this, batch $10 \mathrm{mg}$ lafutidine was dissolved in polyethylene glycol 600, which was used as a non-volatile solvent. The drug solution was added to avicel PH 101 (carrier material) and mixed properly in mortar and pestle. This mixture was allowed to stand for 10 minutes then add aerosil-200 as a coating material to obtain free-flowing powder. Finally, 5\% of sodium starch glycolate (disintegrant), 5\% polyvinyl pyrrolidone $\mathrm{k} 30$ (binder), and 1\% magnesium stearate (lubricant) was added to the above mixture and mixed thoroughly. The final mixture was compressed into tablets by using rotary tablet machine, and liquisolid tablets were evaluated for pre- and post-compression characteristics. ${ }^{[13]}$

A $3^{2}$ randomized full factorial design was used in the present study. In this design, two independent factors were evaluated, each at three levels, and experimental trials were performed for all nine possible combinations. The carrier to coating material ratio $\left(\mathrm{X}_{1}\right)$ and polyethylene glycol $600\left(\mathrm{X}_{2}\right)$ was chosen as independent variables in $3^{2}$ full factorial design, while hardness $\left(Y_{1}\right)$, angle of repose $\left(\mathrm{Y}_{2}\right), \%$ of cumulative drug release at 5 minutes $Q_{5}\left(Y_{3}\right)$, and disintegration time $\left(\mathrm{Y}_{4}\right)$ were taken as dependent variables. Multiple linear regression analysis, ANOVA, and graphical representation of the influence of factor by contour plots were performed using Design Expert 7. ${ }^{[13,14]}$ The experimental runs and measured responses of $3^{2}$ full factorial design batches of lafutidine liquisolid tablets were depicted in Table 4. The desirability function approach is one of the most widely used methods for the optimization of multiple response processes. The desirability function combines all the responses into one variable to predict the optimum levels for the independent variables. A desirability value of 0 represents an unacceptable value for the responses, and a value of 1 represents the most desired value for the responses. ${ }^{[14]}$

\section{Evaluation of Lafutidine Liquisolid Tablets}

Pre-compression and solid dispersions were evaluated for bulk density, tapped density, Hausner ratio, Carr's compressibility index, and angle of repose as described by Khalid E et. al. and Boghra R et. al. Post compression parameters, like weight variation, thicknesses, hardness, friability, content uniformity, and disintegration time studies were performed, as described by Babatunde A et al., Javadzadeh Y et. al., and Spiro S et al. ${ }^{[15-19]}$

\section{In vitro Drug Release Study}

This study was carried out by using a United States Pharmacopeia (USP) type-II dissolution test apparatus (apparatus 2, $100 \mathrm{rpm}, 37 \pm 0.5^{\circ} \mathrm{C}$ ) in stimulated gastric fluid without enzyme-containing $0.1 \mathrm{~N} \mathrm{HCl}$. Aliquots of $10 \mathrm{~mL}$ were withdrawn at different time interval. Solution filtered through $0.45 \mu \mathrm{m}$ filter paper and the content of lafutidine was analyzed using UV spectrophotometer at $286 \mathrm{~nm} .{ }^{[20,21]}$

\section{Stability Studies}

According to ICH guideline stability studies of optimized formulation was determined by using stability chamber (make: Remi Equipments Ltd., Mumbai, model-CHM-6S), and the samples placed in screw-capped vials under ambient conditions at $40^{\circ} \mathrm{C}$ and $75 \% \mathrm{RH}$ for 3 months. The selected formulation was evaluated for their hardness, friability, disintegration time, in vitro drug release, and drug content. The similarity factor $\left(f_{2}\right)$ was used to evaluate the drug release.

$$
f_{2}=\text { Ð } \log \left[\left\{1+\frac{1}{n} \sum_{t=1}^{n}\left(R_{t}-T_{t}\right)^{2}\right\}^{-0.5} x 100\right]
$$

Where $\log$ is logarithm to the base $10, n$ is the number of time points, $\sum$ is summation over all time points, $R_{t}$ is

Table 2: Formulation of $3^{2}$ full factorial design batches of lafutidine $10 \mathrm{mg}$ liquisolid tablets

\begin{tabular}{|c|c|c|c|c|c|c|c|c|}
\hline Batch & $\begin{array}{l}\text { Lafutidine } \\
\text { (mg) }\end{array}$ & $\begin{array}{l}P E G-600 \\
(\mathrm{mg})\end{array}$ & $\begin{array}{l}\text { Total wt. of } \\
\text { liquid } \\
(\mathrm{W}) \\
(\mathrm{mg})\end{array}$ & $\begin{array}{l}\text { Ratio of } \\
\text { carrier to } \\
\text { coating } \\
(R)\end{array}$ & $\begin{array}{l}\text { Liquid load } \\
\text { factor } \\
\left(L_{f}\right)\end{array}$ & $\begin{array}{l}\text { Avicel } \\
\text { PH } 101 \\
(\mathrm{mg}) \\
(\mathrm{Q})\end{array}$ & $\begin{array}{l}\text { Aerosil-200 } \\
(\mathrm{mg}) \\
(q)\end{array}$ & $\begin{array}{l}\text { Wt. of tablets } \\
(\mathrm{mg})\end{array}$ \\
\hline $\mathrm{F}_{1}$ & 10 & 35.06 & 5 & 45.06 & 0.3227 & 139.63 & 27.92 & 235.99 \\
\hline $\mathrm{F}_{2}$ & 10 & 35.06 & 12.5 & 45.06 & 0.2416 & 186.5 & 14.92 & 273.58 \\
\hline $\mathrm{F}_{3}$ & 10 & 35.06 & 20 & 45.06 & 0.2213 & 203.61 & 10.18 & 287.33 \\
\hline $\mathrm{F}_{4}$ & 10 & 58.43 & 5 & 68.43 & 0.3227 & 212.05 & 42.41 & 358.39 \\
\hline $\mathrm{F}_{5}$ & 10 & 58.43 & 12.5 & 68.43 & 0.2416 & 283.23 & 22.65 & 415.47 \\
\hline $\mathrm{F}_{6}$ & 10 & 58.43 & 20 & 68.43 & 0.2213 & 309.21 & 15.46 & 436.33 \\
\hline $\mathrm{F}_{7}$ & 10 & 81.8 & 5 & 91.8 & 0.3227 & 284.47 & 56.89 & 480.79 \\
\hline $\mathrm{F}_{8}$ & 10 & 81.8 & 12.5 & 91.8 & 0.2416 & 379.96 & 30.39 & 557.37 \\
\hline $\mathrm{F}_{9}$ & 10 & 81.8 & 20 & 91.8 & 0.2213 & 414.82 & 20.74 & 585.35 \\
\hline
\end{tabular}

All the formulations contain 5\% SSG, 5\% PVP K-30, and 1\% MG stearate 
the mean dissolution value of the reference profile at time $t$, and $T_{t}$ is the mean dissolution value of the test profile at the same time point. The USFDA draft guidance document contains more information on similarity factor $\left(f_{2}\right)$. The value of similarity factor $\left(f_{2}\right)$ between 50 and 100 suggests that the two dissolution profiles are similar. ${ }^{[22]}$

\section{RESULTS AND DiscusSion}

\section{Characterization and Drug-Excipients Compatibility Study}

Lafutidine maximum absorbance was found to be at $286 \mathrm{~nm}$ in $0.1 \mathrm{~N} \mathrm{HCl}$. Compatibility study of lafutidine was carried out to determine the drug-excipients interaction. FTIR spectra of lafutidine and formulation were recorded using $\mathrm{KBr}$ mixing method on FTIR instrument. The FTIR spectra of pure drug and formulation are shown in Figs $1 \mathrm{~A}$ and $\mathrm{B}$. Lafutidine exhibited peaks due to $\mathrm{C}=\mathrm{O}, \mathrm{C}-\mathrm{H},-$ $\mathrm{CH}_{2}, \mathrm{~S}=\mathrm{O}$, and C-S stretching. It was observed that there were no or very minor changes in drug main peaks in the IR spectra of the drug and formulation. The FTIR study revealed no physical or chemical interaction of drug with excipient. The DSC thermograms of lafutidine showed in Fig. 1C, sharp endothermic peak at $104.22^{\circ} \mathrm{C}$, indicating that the drug is highly crystalline. The absence of drug peak in the thermograms of formulation (Fig. 1C) indicated the drug was converted into an amorphous form. The intensity of the endotherm was markedly decreased in
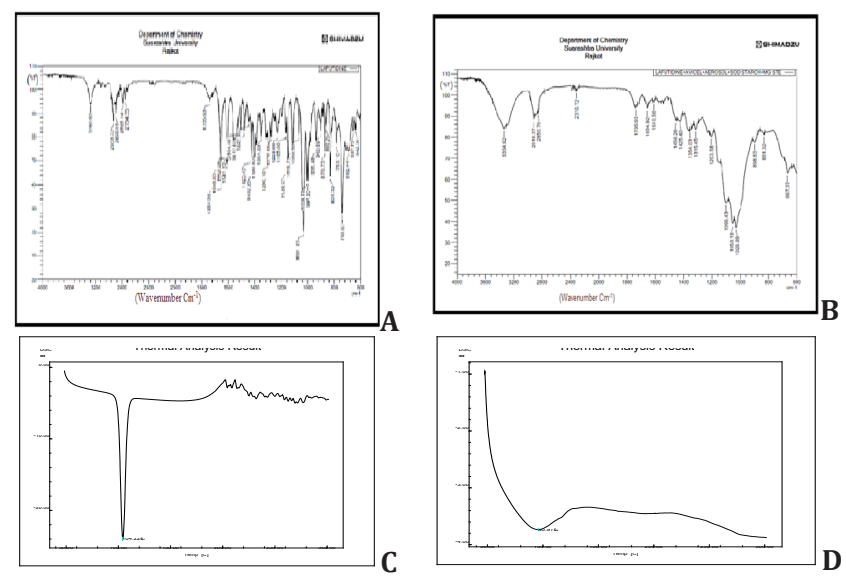

Fig. 1: Characterization and drug-excipients compatibility study; A: FTIR spectra of pure lafutidine; B: FTIR spectra of formulation; C: DSC thermogram of pure lafutidine; D: DSC thermogram of lafutidine liquisolid table checkpoint batch

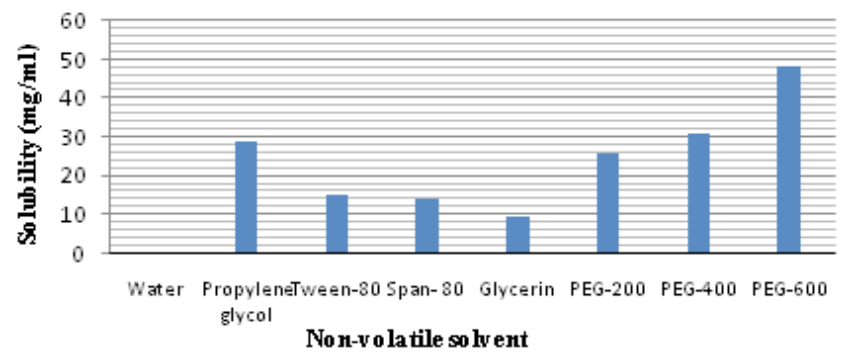

Fig 2: Solubility of lafutidine in different non-volatile solvents the liquisolid formulation. It was shown that reduction in the crystallinity of the drug give faster drug release from the formulation.

\section{Preliminary Screening of Non-Volatile Solvents, Carrier Materials, and Coating Materials}

\section{Selection of Non-Volatile Solvent}

Non-volatile solvent was selected based on the solubility study. The solubility of lafutidine in different non-volatile solvent like propylene glycol, PEG 200, PEG 400, PEG 600, glycerin, span 80 , and tween 80 were determined. The results of solubility of lafutidine in various non-volatile solvent were shown in Fig. 2. On the base of saturated solubility study, lafutidine has maximum solubility in PEG-600 (48.16 mg/mL); so, PEG-600 was selected as non-volatile solvent for the formulation of liquisolid tablet.

\section{Selection of Carrier and Coating Material}

Screening of carrier and coating material base on liquid retention potential ( $\Phi$ value). Angle of repose determination is an important step in the development of liquisolid tablets. The relationship of angle of repose with corresponding liquid retention potential of carrier, like avicel PH 101, avicel PH 102, and lactose, are shown in Fig. 3A. From the result, it was concluded when the amount of PEG-600 increases the angle of repose increase, which results in decrease in flow property of powder. The $\emptyset$ value which corresponded to an angle of repose $33^{\circ}$ was reported to represent the flowable liquid retention potential of powder admixture. Here, avicel PH 101 has 0.1876 highest $\emptyset$ value was found at angle of repose corresponding to the $33^{\circ}$. So, avicel PH 101 was selected as carrier material. The relationship of angle of repose with corresponding liquid retention potential of coating material like aerosil, aerosil 200, and cab-o-siare
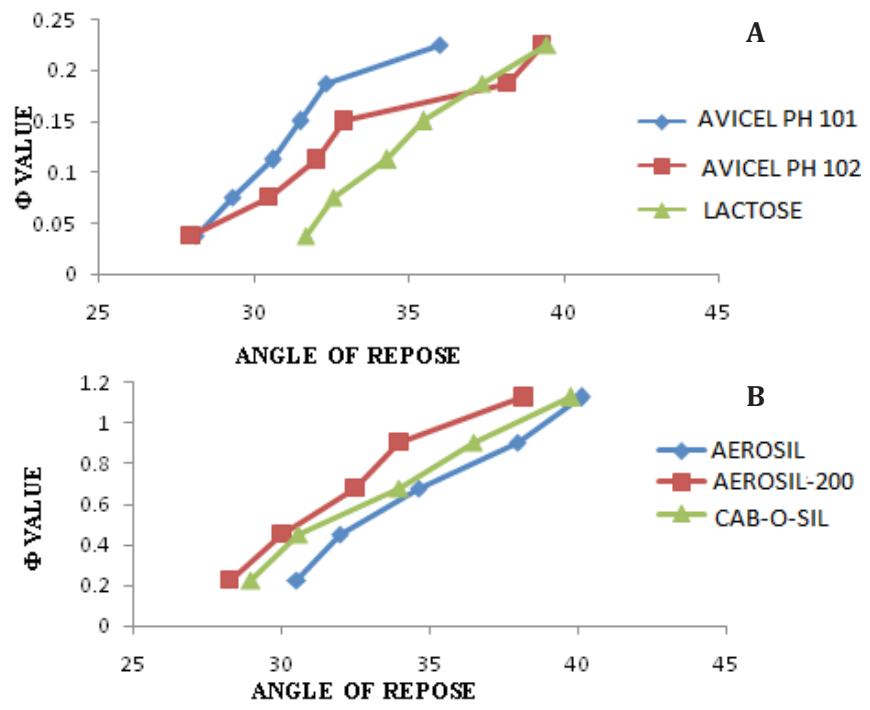

Fig. 3: A: Comparison of $\varnothing$ value of carrier materials in PEG-600; B: Comparison of $\varnothing$ value of coating materials in PEG-600 
are shown in Fig. 3B. Result shown that when PEG-600 increases angle of repose increase, which results in decrease in flow property of powder. Here, aerosil-200 has 0.6755 highest $\varnothing$ value was found at angle of repose corresponding to the $33^{\circ}$. So, aerosil-200 was selected as coating material. The angle of repose of coating material aerosil-200 has highest liquid retention potential (0.6755) compared to other coating material at $33^{\circ}$. So, we have selected avicel PH 101 as carrier material and aerosil-200 as coating material.

\section{Evaluation of Preliminary Trial Batches of Lafutidine Liquisolid Tablets}

To find out the effect of carrier to coating material ratio (R) and amount of non-volatile solvent (PEG-600) for that various trial batches were formulated and evaluated for pre- and post-compression characteristic parameters result are shown in Table 3. Batch T1, T2, T3 and $\mathrm{T}_{4}$ was shown acceptable characteristics of liquisolid tablets, where batch T5 had not acceptable hardness and friability. Therefore, carrier to coating material ratio was more than 20; it was difficult to formulate of liquisolid tablet. Hence, further trials were carried out using combination of carrier to coating material ratio (R) and PEG-600 in order to understand their effect, and to optimize concentration of both for desired release profile.

\section{Evaluation of Full Factorial Batches of Lafutidine Liquisolid Tablets}

Full factorial batches some evaluation are summarized in Tables 4 and 5 . It was cleared that all the batches $\mathrm{F}_{1}$ to $\mathrm{F}_{9}$ showed good flow properties. Bulk density and tapped density were found to be in range $0.37 \pm 0.02$ to $0.5 \pm 0.08$, and $0.44 \pm 0.05$ to $0.57 \pm 0.07$, respectively. Values of Care's index and Hausner ratio were found according to an acceptable limit. Minimum angle of repose was found to be $21.66 \pm 0.6^{\circ}$, and maximum was $27.35 \pm 0.49^{\circ}$, which indicated adequate powder flow property. Variation in angle of repose could be attributed to the presence of PEG-600 in the formulations. Angle of repose was showed that when carrier to coating material ratio ( $R$ value) increase, there was increase in angle of repose. $F_{1}$ had a lowest angle of repose because of low amount of PEG-600 and low amount of carrier to coating material ratio (R). Hardness of liquisolid tablets decrease as ratio of carrier to coating and amount of PEG-600 increased. Result of weight variation and friability were also according to acceptable limit. Disintegration time was found in range $1.03 \pm 0.05$ to $4.95 \pm 0.02$. When the

Table 3: Evaluation of preliminary trial batches of lafutidine liquisolid tablets

\begin{tabular}{lllllll}
\hline Batch & $\begin{array}{l}\text { Angle of repose } \\
(\theta)\end{array}$ & $\begin{array}{l}\text { Hardness } \\
\left(\mathrm{kg} / \mathrm{cm}^{2}\right)\end{array}$ & Friability (\%) & Drug content (\%) & $\begin{array}{l}\text { Disintegration time } \\
(\mathrm{min})\end{array}$ & $\begin{array}{l}\text { \% drug release at } \\
60 \mathrm{~min}\end{array}$ \\
\hline T1 & $27.96 \pm 0.36$ & $4.2 \pm 0.28$ & $0.2 \pm 0.01$ & $91.3 \pm 0.04$ & $1.03 \pm 0.05$ & $55 \pm 1.5$ \\
T2 & $29 \pm 0.53$ & $4.3 \pm 0.28$ & $0.33 \pm 0.02$ & $92.2 \pm 0.04$ & $2.06 \pm 0.11$ & $64.5 \pm 1.2$ \\
T3 & $30.59 \pm 0.56$ & $4.1 \pm 0.28$ & $0.52 \pm 0.01$ & $94.7 \pm 0.04$ & $2.15 \pm 0.05$ & $74.3 \pm 1.1$ \\
T4 & $31.5 \pm 0.27$ & $3.9 \pm 0.28$ & $0.82 \pm 0$ & $98.8 \pm 0.04$ & $2.5 \pm 0.23$ & $85.5 \pm 1.1$ \\
T5 & $34.1 \pm 0.18$ & $2.5 \pm 0.28$ & $1.16 \pm 0.05$ & $98.4 \pm 0.04$ & $2.9 \pm 0.17$ & $90.8 \pm 1.2$ \\
\hline
\end{tabular}

Table 4: Runs and measured responses of $3^{2}$ factorial design batches

\begin{tabular}{|c|c|c|c|c|c|c|}
\hline Batch & $\begin{array}{l}\text { Ratio of carrier to } \\
\text { coating material } R \\
\left(X_{1}\right)\end{array}$ & $\begin{array}{l}\text { Amount of PEG- } \\
600\left(X_{2}\right)\end{array}$ & Hardness $\left(Y_{1}\right)$ & Angle of repose $\left(Y_{2}\right)$ & $\begin{array}{l}\% \text { cumulative drug } \\
\text { release at } 5 \text { min } Q_{5} \\
\left(Y_{3}\right)\end{array}$ & $\begin{array}{l}\text { Disintegration time } \\
\left(Y_{4}\right)\end{array}$ \\
\hline $\mathrm{F}_{1}$ & -1 & -1 & $4.72 \pm 0.1$ & $21.66 \pm 0.6$ & $15.09 \pm 0.07$ & $3.47 \pm 0$ \\
\hline $\mathrm{F}_{2}$ & 0 & -1 & $4.62 \pm 0.05$ & $23.34 \pm 1.43$ & $15.84 \pm 0.07$ & $3.61 \pm 0.1$ \\
\hline $\mathrm{F}_{3}$ & 1 & -1 & $3.82 \pm 0.1$ & $24.99 \pm 0.08$ & $14.23 \pm 0.08$ & $4.95 \pm 0.02$ \\
\hline $\mathrm{F}_{4}$ & -1 & 0 & $4.98 \pm 0.05$ & $23.66 \pm 1.59$ & $24.92 \pm 0.04$ & $2.33 \pm 0.33$ \\
\hline $\mathrm{F}_{5}$ & 0 & 0 & $4.68 \pm 0$ & $24.68 \pm 1.08$ & $25.88 \pm 0.08$ & $2.40 \pm 0.02$ \\
\hline $\mathrm{F}_{6}$ & 1 & 0 & $4.14 \pm 0$ & $25.88 \pm 1.92$ & $26.36 \pm 0.08$ & $2.55 \pm 0$ \\
\hline $\mathrm{F}_{7}$ & -1 & 1 & $5.00 \pm 0.05$ & $23 \pm 1.43$ & $27.09 \pm 0.04$ & $1.03 \pm 0.05$ \\
\hline $\mathrm{F}_{8}$ & 0 & 1 & $4.54 \pm 0.1$ & $25.1 \pm 0.41$ & $23.45 \pm 0.04$ & $1.16 \pm 0.05$ \\
\hline $\mathrm{F}_{9}$ & 1 & 1 & $3.55 \pm 0.05$ & $27.35 \pm 0.49$ & $24.21 \pm 0.04$ & $2.10 \pm 0.05$ \\
\hline \multicolumn{7}{|c|}{ Factors and the levels in the design } \\
\hline \multicolumn{3}{|c|}{ Independent variables } & $\operatorname{Low}(-1)$ & Medium (0) & \multicolumn{2}{|l|}{$\operatorname{High}(1)$} \\
\hline \multicolumn{3}{|c|}{ Carrier to coating material ratio $\mathrm{R}\left(\mathrm{X}_{1}\right)$} & 5 & 12.5 & \multicolumn{2}{|l|}{20} \\
\hline \multicolumn{3}{|c|}{ Amount of PEG-600 $\left(\mathrm{X}_{2}\right)$} & 35.06 & 58.43 & \multicolumn{2}{|l|}{81.8} \\
\hline
\end{tabular}


Table 5: Evaluation of full $3^{2}$ factorial batches of lafutidine liquisolid tablets

\begin{tabular}{lllll}
\hline Batch & Weight variation $(\mathrm{mg})$ & Friability $(\%)$ & Drug content $(\%)$ & \% drug release at 60 min \\
\hline $\mathrm{F}_{1}$ & $235.9 \pm 0.15$ & $0.37 \pm 0.01$ & $94.33 \pm 0.8$ & $84.72 \pm 0$ \\
$\mathrm{~F}_{2}$ & $273.5 \pm 0.24$ & $0.42 \pm 0.01$ & $98.12 \pm 0.87$ & $86.28 \pm 0.04$ \\
$\mathrm{~F}_{3}$ & $287.3 \pm 0.29$ & $0.29 \pm 0.01$ & $97.29 \pm 0.14$ & $82.46 \pm 0.04$ \\
$\mathrm{~F}_{4}$ & $358.1 \pm 0.35$ & $0.12 \pm 0.01$ & $95.26 \pm 0.88$ & $92.50 \pm 0.08$ \\
$\mathrm{~F}_{5}$ & $415.2 \pm 0.34$ & $0.5 \pm 0.01$ & $97.17 \pm 0.87$ & $93.50 \pm 0.43$ \\
$\mathrm{~F}_{6}$ & $436.5 \pm 0.56$ & $0.44 \pm 0.01$ & $98.12 \pm 0.2$ & $94.84 \pm 0.08$ \\
$\mathrm{~F}_{7}$ & $480.6 \pm 0.55$ & $0.19 \pm 0$ & $96.8 \pm 0.61$ & $98.66 \pm 0.08$ \\
$\mathrm{~F}_{8}$ & $557.1 \pm 0.59$ & $0.28 \pm 0.01$ & $98.47 \pm 0.24$ & $95.55 \pm 0.04$ \\
$\mathrm{~F}_{9}$ & $585.2 \pm 0.65$ & $0.49 \pm 0.01$ & $97.57 \pm 0.33$ & $97.84 \pm 0.04$ \\
\hline
\end{tabular}

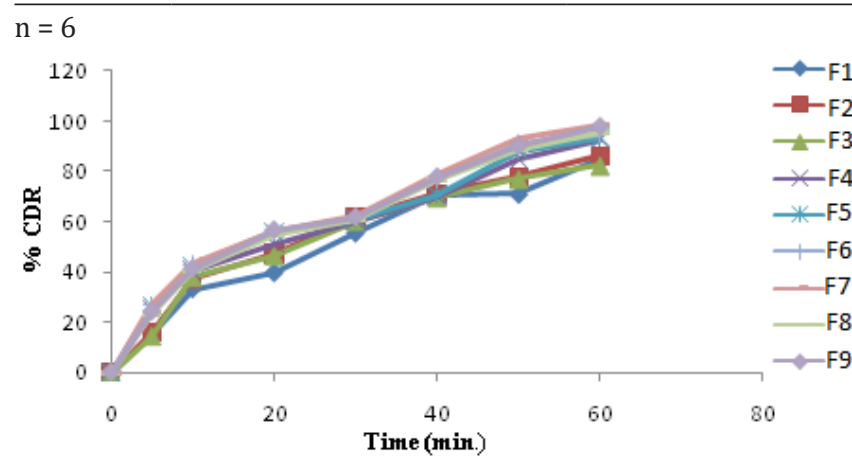

Fig. 4: In vitro drug release profile of liquisolid tablets of lafutidine
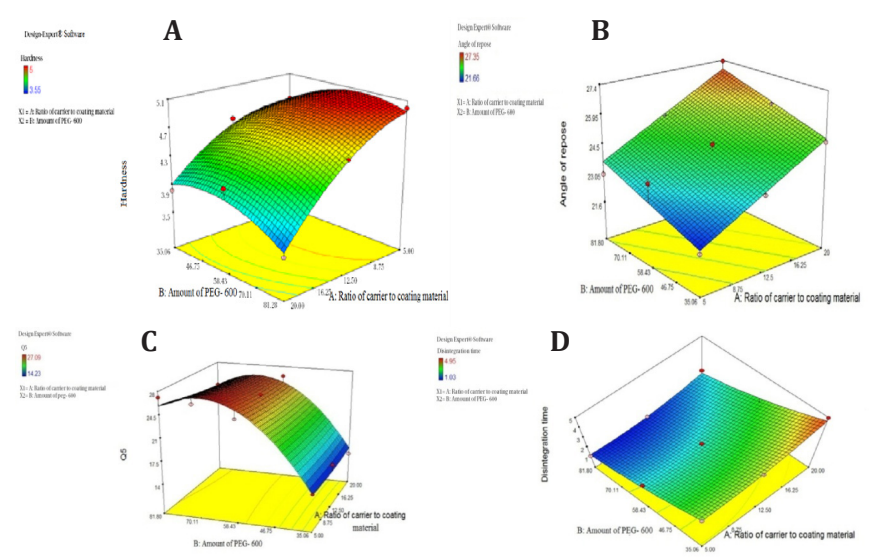

Fig. 5: 3D plot showing the effect of carrier to coating material ratio $\mathrm{R}\left(\mathrm{X}_{1}\right)$ and PEG-600 $\left(\mathrm{X}_{2}\right)$ on: A: Hardness; B: Angle of repose; C: $\%$ of cumulative drug release at 5 minutes Q5; D: disintegration time

amount of PEG-600 was increased, disintegration time also increased. In vitro dissolution studies of all batches are shown in Fig. 4. The batch $\mathrm{F}_{7}$ was shown highest drug release of $98.66 \pm 1.52 \%$ at 60 minutes. While batch $\mathrm{F}_{3}$ has shown lowest $82.46 \pm 0.04 \%$ drug release at 60 minutes.

\section{$3^{2}$ Full Factorial Design Model Evaluation}

A statistical model incorporating interactive and polynomial terms was used to evaluate the responses:

$$
\mathrm{Y}=\mathrm{b}_{0}+\mathrm{b}_{1} \mathrm{X}_{1}+\mathrm{b}_{2} \mathrm{X}_{2}+\mathrm{b}_{11} \mathrm{X}_{1}^{2}+\mathrm{b}_{22} \mathrm{X}_{2}^{2}+\mathrm{b}_{12} \mathrm{X}_{1} \mathrm{X}_{2}
$$

Where $Y$ is the dependent variable, $b_{0}$ is the arithmetic mean response of the nine runs, and any $b_{i}$ is the estimated coefficients for the related factor $\mathrm{X}_{\mathrm{i}}$. The main effects $\left(\mathrm{X}_{1}\right.$ and $\mathrm{X}_{2}$ ) represent the average result of changing one factor at a time from its low to high value. The polynomial terms $\left(\mathrm{X}_{1}{ }^{2}\right.$ and $\left.\mathrm{X}_{2}{ }^{2}\right)$ are included to investigate nonlinearity. The interaction term " $X_{1} X_{2}$ " shows how the response changes when the two factors change simultaneously. The fitted equations relating the responses, i.e., carrier to coating material ratio $\mathrm{R}\left(\mathrm{X}_{1}\right)$ and PEG-600 $\left(\mathrm{X}_{2}\right)$ on hardness $\left(\mathrm{Y}_{1}\right)$, angle of repose $\left(\mathrm{Y}_{2}\right), \%$ of cumulative drug release at 5 minutes $\mathrm{Q} 5\left(\mathrm{Y}_{3}\right)$, and disintegration time $\left(\mathrm{Y}_{4}\right)$. The polynomial equations can be used to draw conclusions after considering the magnitude of coefficient and the mathematical sign it carries (i.e., positive or negative). The results of ANOVA suggested that calculated $F$ values for hardness, angle of repose, $\%$ of cumulative drug release at 5 minutes Q5, and disintegration time are $21.58,15.06,16.63$, and 14.69 , respectively, as shown in Table 6. Tabulated F value was found to be 9.013 at $\alpha=0.05$. Calculated $F$ values are greater than tabulated for all dependent variables therefore, factors selected have shown significant effects. From the results of multiple regression analysis, it was found that all factors had statistically significant influence on all dependent variables as $\mathrm{p}<0.05$.

\section{Effect of Formulation Variable on Hardness $\left(Y_{1}\right)$}

$\mathrm{Y}_{1}=4.76-0.53 \mathrm{X}_{1}-0.012 \mathrm{X}_{2}-0.14 \mathrm{X}_{1} \mathrm{X}_{2}-0.25 \mathrm{X}_{1}^{2}-0.23 \mathrm{X}_{2}^{2}$ From the $3 \mathrm{D}$ response surface plot (Fig. 5A) and the regression coefficient values of factors, it was concluded that hardness of lafutidine liquisolid tablets decrease with increase in amount of ratio of carrier to coating material (R) and amount of PEG-600. From regression it is observed $\mathrm{X}_{1}, \mathrm{X}_{2}, \mathrm{X}_{1} \mathrm{X}_{2}$, and $\mathrm{X}_{2}{ }^{2}$ were significant model terms, which affect the on hardness. Interaction and nonlinearity was not observed. The results also indicated that the ratio of carrier to coating material was given a more significant effect on hardness as compared to PEG-600. The value of correlation coefficient $\left(\mathrm{R}^{2}\right)$ was found to be 0.9306 .

Effect of Formulation Variables on Angle of Repose $\left(Y_{2}\right)$

$\mathrm{Y}_{2}=24.7+1.65 \mathrm{X}_{1}+0.91 \mathrm{X}_{2}+0.25 \mathrm{X}_{1} \mathrm{X}_{2}-0.05 \mathrm{X}_{1}{ }^{2}-0.5 \mathrm{X}_{2}{ }^{2}$

The results of multiple regression analysis and $3 \mathrm{D}$ response surface plot (Fig. 5B) showed that coefficient $b_{1}$ and $b_{2}$ bear 
Lafutidine Liquisolid Tablets

Table 6: Results of the ANOVA for dependent variables

\begin{tabular}{|c|c|c|c|c|c|}
\hline \multicolumn{6}{|l|}{ Hardness } \\
\hline Source of variation & $D F$ & SS & $M S$ & $F$ & $p$ \\
\hline Regression & 5 & 01.99 & 0.4 & 21.58 & 0.0147 \\
\hline Residual & 3 & 00.055 & 0.018 & & \\
\hline Total & 8 & 2.05 & & & \\
\hline \multicolumn{6}{|l|}{ Angle of repose } \\
\hline Source of variation & $D F$ & SS & $M S$ & $F$ & $p$ \\
\hline Regression & 5 & 022.07 & 4.41 & 15.06 & 0.0246 \\
\hline Residual & 3 & 000.88 & 0.29 & & \\
\hline Total & 8 & 022.95 & & & \\
\hline \multicolumn{6}{|c|}{$\%$ of cumulative drug release at $5 \mathrm{~min}\left(Q_{5}\right)$} \\
\hline Source of variation & $D F$ & SS & $M S$ & $F$ & $P$ \\
\hline Regression & 5 & 213.75 & 42.75 & 16.63 & 0.0214 \\
\hline Residual & 3 & 007.71 & 2.57 & & \\
\hline Total & 8 & 221.46 & & & \\
\hline \multicolumn{6}{|l|}{ Disintegration time } \\
\hline Source of variation & $D F$ & $S S$ & MS & $F$ & $p$ \\
\hline Regression & 5 & 011.72 & 2.34 & 14.69 & 0.0255 \\
\hline Residual & 3 & 000.48 & 0.16 & & \\
\hline Total & 8 & 012.2 & & & \\
\hline
\end{tabular}

$\mathrm{DF}$ is degree of freedom; SS is sum of square; MS is mean square; F is Fischer's ratio

a positive; that indicates when the amount of carrier to coating material ratio (R) and amount of PEG-600 was increase, the angle of repose was also increase. Sign of $b_{12}$ is positive, which indicates that combine effects of $\mathrm{X}_{1}$ and $\mathrm{X}_{2}$ is positive on the angle of repose variable. The results also indicated that the ratio of carrier to coating material was given a more significant effect on angle of repose as compared to PEG-600. The value of correlation coefficient $\left(\mathrm{R}^{2}\right)$ was found to be 0.9517 .

Effect of Formulation Variables on \% of Cumulative Drug Release at 5 Minutes $\left(Q_{5}\right)\left(Y_{3}\right)$

$\mathrm{Y}_{3}=26.44-0.39 \mathrm{X}_{1}+5.93 \mathrm{X}_{2}-0.6 \mathrm{X}_{1} \mathrm{X}_{2}-0.29 \mathrm{X}_{1}{ }^{2}-0.3 \mathrm{X}_{2}{ }^{2}$ The results of multiple regression analysis and $3 \mathrm{D}$ response surface plot (Fig. 5C) showed that coefficient $b_{1}$ bears a negative sign and coefficient $b_{2}$ bear positive sign. The negative sign indicates that as the amount of carrier to coating material ratio increases, there is decrease in the \% of cumulative drug release at 5 minutes $\left(Q_{5}\right)$. The positive sign indicates that as the amount of $\%$ of cumulative drug release at 5 minutes $\left(Q_{5}\right)$. Sign of $b_{12}$ is negative, which indicates that combine effect of $X_{1}$ and $\mathrm{X}_{2}$ is negative on the $\mathrm{Q}_{5}$ variable. The value of correlation coefficient $\left(R^{2}\right)$ was found to be 0.9414 .

Effect of Formulation Variables on Disintegration Time $\left(Y_{4}\right)$ $\mathrm{Y} 4=2.19+0.46 \mathrm{X}_{1}-1.29 \mathrm{X}_{2}+0.1 \mathrm{X}_{1} \mathrm{X}_{2}+0.34 \mathrm{X}_{1}^{2}+0.29 \mathrm{X}_{2}^{2}$ From the 3D response surface plot (Fig. 5A) and the regression coefficient values of factors, it was concluded that when carrier to coating material ratio $(\mathrm{R})$ increases, the disintegration time is also increased. The negative sign of $\mathrm{X}_{2}$ coefficient indicates that as the amount of PEG- 600 increase, the disintegration time was decreased. Sign of $b_{12}$ is positive, which indicate that combine effect of $X_{1}$ and $X_{2}$ is positive on the disintegration time variable. The value of correlation coefficient $\left(R^{2}\right)$ was found to be 0.9506 .

\section{Formulation and Evaluation of Check Point Batch}

A checkpoint batch was designed according to the desirability function, as shown in Table 7. To validate the evolved mathematical, a checkpoint batch was prepared and evaluated under the same conditions as outlined for the other batches. The response data was compared with that of the required data. The results were found within acceptable limit that assure adequate composition of liquisolid tablets of lafutidine. The application of desirability function gives possibility to predict the optimum levels for the independent variables. In this study, the following constraints were arbitrarily used for the selection of an optimized batch: hardness: 3 to 5.5, angle of repose: 25 to $30, \%$ of cumulative drug release at 5 minutes $\left(Q_{5}\right)>27.09 \%$, and disintegration time $<1.3$ minutes. Desirability value was close to one, in different criteria for the optimization of lafutidine $10 \mathrm{mg}$ liquisolid tablets, as shown in Table 7. All four responses were targeted in order to get desired release profile. The partial desirability function (di) of each of the responses and the calculated geometric mean as the maximum global desirability 
Tushar Gohil et al.

Table 7: Formulation and evaluation of checkpoint batch and comparison with predicted value

\begin{tabular}{|c|c|c|c|c|c|}
\hline \multicolumn{3}{|c|}{ Ingredients } & \multicolumn{3}{|c|}{ Formulation (mg) } \\
\hline \multicolumn{3}{|c|}{ Lafutidine } & \multicolumn{3}{|l|}{10} \\
\hline \multicolumn{3}{|c|}{ Amount of PEG-600 } & \multicolumn{3}{|l|}{79.54} \\
\hline \multicolumn{3}{|c|}{ Ratio of carrier to coating (R) } & \multicolumn{3}{|l|}{5.5} \\
\hline \multicolumn{3}{|c|}{ Liquid load factor $\left(\mathrm{L}_{\mathrm{f}}\right)$} & \multicolumn{3}{|l|}{0.3104} \\
\hline \multicolumn{3}{|c|}{ Avicel PH 101} & \multicolumn{3}{|l|}{288.46} \\
\hline \multicolumn{3}{|c|}{ Aerosil-200 } & \multicolumn{3}{|l|}{52.44} \\
\hline \multicolumn{3}{|c|}{ Sodium starch glycolate } & \multicolumn{3}{|l|}{21.52} \\
\hline \multicolumn{3}{|c|}{ Polyvinyl pyrrolidone K-30 } & \multicolumn{3}{|l|}{21.52} \\
\hline \multicolumn{3}{|c|}{ MG Stearate } & \multicolumn{3}{|l|}{4.3} \\
\hline \multicolumn{3}{|l|}{ Total } & \multicolumn{3}{|l|}{477.78} \\
\hline$X_{1}$ & $X_{2}$ & Parameters & Predicted & Observed & Bias (\%) \\
\hline \multirow{4}{*}{\multicolumn{2}{|c|}{79.54}} & Hardness $\left(\mathrm{Y}_{1}\right)$ & 5.15 & 5 & 2.91 \\
\hline & & Angle of repose $\left(\mathrm{Y}_{2}\right)$ & 28.04 & 27.43 & 2.17 \\
\hline & & $\mathrm{Q} 5\left(\mathrm{Y}_{3}\right)$ & 27.54 & 26.09 & 5.26 \\
\hline & & Disintegration time $\left(\mathrm{Y}_{4}\right)$ & 1.97 & 1.1 & 9.09 \\
\hline
\end{tabular}

Desirability

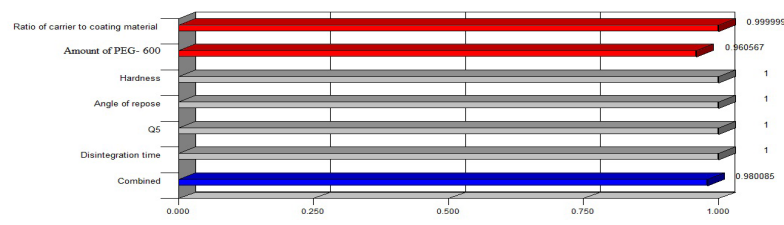

Fig. 6: Desirability values of responses

function ( $D=1)$, are presented in Fig. 6. The optimized batch results are found to be within the pharmacopoeial limits and showed highest drug release of $99.06 \pm 0.08 \%$ at 60 minutes. The stability study was performed according to ICH guideline. The optimized formulation was kept at $40^{\circ} \mathrm{C}$ and $75 \% \mathrm{RH}$ in order to check out the stability of the liquisolid tablet. The samples were analyzed for various evaluation parameters before and after stability study. The results showed similarity with that of earlier evaluated parameters. There is no significant difference between, before and after stability of optimized formulation. Hence, the formulation was found to be stable during accelerated stability study. The similarity factor $(f 2)$ was found to be 71.25 at accelerated condition $\left(40^{\circ} \mathrm{C}\right.$ and $\left.75 \% \mathrm{RH}\right)$.

The present investigation lafutidine $10 \mathrm{mg}$ liquisolid tablet was successfully formulated. There was no drugexcipient interaction found in FTIR and DSC study. Preliminary screening of non-volatile solvents, carrier materials, and coating materials were conducted to select the suitable excipients. From the results of preliminary studies, PEG-600 was used as non-volatile solvent, avicel PH 101, and aerosil-200 were used as carrier and coating material. The carrier to coating material ratio $\left(\mathrm{X}_{1}\right)$ and polyethylene glycol $600\left(\mathrm{X}_{2}\right)$ was chosen as independent variables in $3^{2}$ full factorial design, while hardness $\left(\mathrm{Y}_{1}\right)$, angle of repose $\left(\mathrm{Y}_{2}\right), \%$ of cumulative drug release at
5 minutes $\mathrm{Q}_{5}\left(\mathrm{Y}_{3}\right)$, and disintegration time $\left(\mathrm{Y}_{4}\right)$, were taken as dependent variables. The effect of independent variables on dependent variables was studied by analyzing response surface plot and polynomial equation. Optimization of lafutidine $10 \mathrm{mg}$ liquisolid tablets was performed by desirability function. A checkpoint batch was designed according to the results of desirability value and evaluated for all the parameters. The results of comparison of predicted response and obtained response were found in good agreement. The formulation was found to be stable during accelerated stability study. Liquisolid technique was proved to be an effective method for solubility enhancement and improving dissolution profile of poorly soluble drug.

\section{ACKNOWLEDGEMENTS}

The authors thank Emcure Pharmaceutical Ltd., Mumbai, for providing lafutidine drug as a gift sample for the present investigation. They also would like to thank Smt. C. V. Gajera Pharmacy Mahila College, Amreli, for providing essential facilities to carry out the research work.

\section{REFERENCES}

1. PatelUB, Modi DC,Shah DP. Liquisolid compacts: Areview. International Journal of Advances in Pharmaceutics. 2017; 6(7):110-113.

2. Patel BB, Shah CN. Recent research on liquisolid technology for solubility enhancement - A review. International Journal of Advance in Pharmaceutics. 2016;5(1):345-394.

3. Komala DR, Janga KY, Jukanti R. Competence of raloxifene hydrochloride loaded liquisolid compacts for improved dissolution and intestinal permeation. J Drug Deliv Sci Technol. 2015;30: 232-241.

4. Pavani E, Noman S, Syed IA. Liquisolid technique based sustained release tablet of trimetazidine dihydrochloride. Drug Invention Today. 2013;5:302-310.

5. Sanka K, Poienti S, Mohd AB. Improved oral delivery of clonazepam 


\section{Lafutidine Liquisolid Tablets}

through liquisolid powder compact formulations: in vitro and ex vivo characterization. Powder Technol. 2014;256:336-344.

6. Khames A. Liquisolid technique: a promising alternative to conventional coating for improvement of drug photostability in solid dosage forms. Drug Deliv. 2013;10:13351343.

7. Oza N, Sagar S. Optimization of dispersible pediatric cefuroxime axetil tablet containing ion-exchange resin as taste masking agent using a $3^{2}$ full factorial design. International Journal of Applied Pharmaceutics. 2019;11(4):325-332.

8. Darshan S, Rushabh S, Hemangi J, Patel PM. Liquisolid technique: a review. Int J Modern Pharm Research. 2013;2:24-34.

9. Vijay KN, Ramarao T, Jayaveer K. Liquisolid compact a novel approach to enhance bioavailability of poorly water soluble drug. Int J Pharm Bio Sci. 2011;1:89-102.

10. Gandhi K, Sawant A, Nagpure S, Deshmane S, Biyani K. Formulation, development, charectrization and evaluation of liquisolid tablet containing pioglitazone HCl. Int J Pharm. 2013;3:122-130.

11. Kaur M, Bala R, Arora S. Formulation and evaluation of liquisolid compacts of amLodipine besylate. Int Res J Pharm. 2013;4(1):156-160.

12. Kanugo A, Chavhan P, Potnis V. Melt evaporation method: a solid dispersion strategy to enhance solubility and dissolution of lafutidine. World J Pharm Res. 2013;2(6):22842300.

13. Ranga S, Jaimini M, Sharma S, Chauhan B, Kumar A. A review on Design of Experiments (DOE). Int J Pharm Chem Sci. 2014;3(1):216-240.
14. Wold N. Use of Experimental Design in the Pharmaceutical Industry. J Pharm Bio Ana. 1991;9(8):605-610.

15. Khalid E, Ahmed S, Mohamed F. Formulation and evaluation of rofecoxib liquisolid tablets. Int J Pharm Sci Rev Res. 2010;3:135-142.

16. Boghra R, Patel A, Desai H, Jadhav A. Formulation and evalution of irbesartan liquisolid tablets. Int J Phar Sci Rev. 2011;9:32-37.

17. Babatunde A, Amal AN, Ebtessam AE, Sahar E. Liquisolid systems to improve the dissolution of furosemide. Sci Pharm. 2010;1:1-20.

18. Javadzadeh Y, Jafari B, Nokhodchi A. Liquisolid technique for dissolution rate enhancement of a high dose water insoluble drug (Carbamazepine). Int J Pharm. 2007;341:26-34.

19. Onodera S, Nishida K, Takeuchi K. Unique Profile of Lafutidine, a novel histamine $\mathrm{H}_{2}$-receptor antagonist mucosal protection throughout gastrointestinal tract mediated by capsaicin-sensitive afferent neurons. Drug Design Rev. 2004;1(2):133-144.

20. Parekh R, Patel P, Patel C, Patel K, Patel H. Development and validation of UV spectrophotometric method for estimation of lafutidine in bulk and pharmaceutical dosage form. Int J Drug Dev Res. 2012;4:325-329.

21. PatilS, Talele G. Gastroretentive mucoadhesive tablet of lafutidine for controlled release and enhanced bioavailability. Drug Del. 2014;22(3):1-8.

22. Cartensen J. ICH Guidelines in Drug Stability Principles and Practices, Edition 2, New York, Marcel Dekker. 1995;514-546.

HOW TO CITE THIS ARTICLE: Gohil T, Oza N, Vekariya H. Quality by design (QbD) approach for enhancement-the dissolution rate of lafutidine liquisolid tablets. Int. J. Pharm. Sci. Drug Res. 2020;12(3):238-246. DOI: 10.25004/IJPSDR.2020.120305 